\section{MARK TULIJ CICERON: O GOVORNIKU}

Prevod: Ksenja Geister,

Opombe in spremna beseda:

David Movrin

Ljubljana: Družina 2002

(Zbirka Sidro; 21)

Recenzija

S tem delom smo končno dobili prevod enega izmed klasikov antične govorništva tudi v knjižni obliki. Sploh je bilo obdobje zadnjih dveh let naklonjeno antiki, govorništvu nasploh in tudi Ciceronu: Izšel je prevod Kennedyjevega dela Klasična retorika ter njena krščanska in posvetna tradicija, izšel je izbor antičnih govornikov.

Delo $O$ govorniku je nastalo leta 55, ko je bil Ciceron že izkušen praktik. Leto poprej je prišlo do sklenitve prvega triumvirata. Ciceron je ostal brez vpliva, a se je zato lahko tem bolj posvetil pisanju. Leta 51 je napisal Državo, leto kasneje se je odpravil službovat v Kilikijo. V državljanski vojni se pridruži Pompeju. Cezar ga po zmagi sicer pomilosti, a se mu s tem dokončno zapre pot v politiko. Po tem ga zadanejo še osebne tragedije, ločitev od Terentije in hčerkina smrt. Po tem se zateče k filozofiji, kjer išče tolažbo.

Delo $O$ govorniku je posvečeno bratu Kvintu. Sestavljajo ga trije pogovori o govorništvu. Glavna protagonista sta Antonij in Kras, sodelujeta pa tudi njuna mlajša kolega Sulpikij in Kota. Pogovor se odvija v Krasovi vili v Tuskulu v začetku septemra leta 91 . V prvem pogovoru najprej poda Kras svoje mnenje o naravi in obsegu govorništva; po njegovem mnenju je govorništvo pomembno za družbo in državo, govornik pa naj bi bil ugledna oseba. Zagovarja svoj cilj, ki je popoln govornik (orator perfectus). Antonij odvr- ne, da se tolikšnega znanja, kot bi ga pri govorniku rad videl Kras, praktično ne da pridobiti. Razvije se debata o tem, kakšna naj bo govornikova izobrazba. Kras razpravlja o razmerju med naravnimi darovi, umetnostjo in vajo (natura, ars in exercitatio). Meni, da mlajša kolega, ki prisostvujeta pogovoru, potrebujeta spodbudo, zato opiše lastno metodo. Antonij meni, da mora govornik biti prepričljiv vjavnih vprašanjih, a zato ne potrebuje široke izobrazbe. Meni, da če hoče govornik vplivati na čustva, ne potrebuje filozofije, ampak svetovljanstvo; študij sicer zelo koristi, a kljub vsemu je najpomembnejša praksa. Kras zaključi pogovor prvega dne s tem, da Antonij samo dokazuje svojo sposobnost zavračanja in naj naslednji dan predstavi svoje videnje govornika.

Drugi dan se pridužita še Katul in Cezar. Antonij začne razpravo s hvalnico govorništvu. Nato se osredotoči na naloge, ki so lastne govorništvu. Kritizira nekaj površnih pravil. Potreben naj bi bil naravni dar in nato veliko vaje. Nadarjeni naj bi lahko shajali tudi brez zgledov. Nato sledi razprava o odkrivanju snovi (inventio). Govora bo tudi o dokazovanju (probare), ki ga prekine ekskurz o grški dialektiki. Kasneje se lahko poučimo tudi o pridobivanju poslušalcev (conciliare) in vplivanju na njihova čustva (movere). Seveda je v govoru potrebna tudi duhovitost, čemur se posveti Cezar. Pogovor nadaljuje Antonij, ki se posveti razpravi o lastnem in nasprotnikovem primeru. Razpravljajo tudi o razporeditvi (dispositio) in zapominjanu (memoria). Razpravo nato sklenejo preložiti na popoldne.

Tretji pogovor se odvija isti dan popoldne. Kras začne $z$ razpravo o slogu in pravilih o krašenju sloga. $\mathrm{Na}$ 
kratko povzame podrobnosti govor- je seznam imen s kratko in pregledniškega okrasja. Izvemo tudi, kako je no razlago. Ceniti pa je treba tudi kratreba nastopati (actio).

Samo delo odlikujejo poleg tekočega prevoda tudi obširne opombe in obsežna spremna beseda. Hvalevreden tek in zgoščen pregled vsebine te brez dvoma zahtevne razprave o tem, kakšen naj bi bil govornik. 